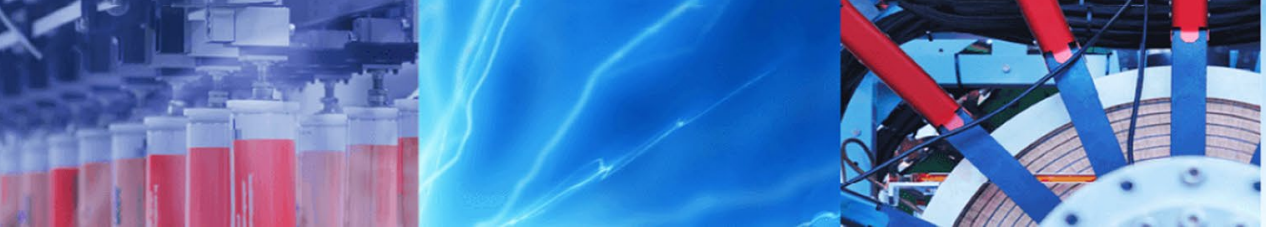

Research Article

\title{
Influence of agriculture fertilizer for the enhanced growth and astaxanthin production from Haematococcus lacustris RRGK isolated from Himachal Pradesh, India
}

\author{
Ramamoorthy Karuppan ${ }^{1} \cdot$ Anand Javee ${ }^{1} \cdot$ Sreekala Kannikulathel Gopidas $^{1} \cdot$ Nagaraj Subramani $^{1}$
}

(c) Springer Nature Switzerland AG 2019

\begin{abstract}
In the present study, Haematococcus lacustris RRGK which is the former name of H. lacustris HPI-001 isolated from Himachal Pradesh, India, and another strain H. lacustris SAG-19a retrieved from Gottingen Culture Collection, Germany, were used. The $\mathrm{H}$. lacustris SAG-19a served as a control. The both strains were grown in a Bold basal medium in which the components of $\mathrm{NaNO}_{3}, \mathrm{~K}_{2} \mathrm{HPO}_{4} \cdot 3 \mathrm{H}_{2} \mathrm{O}$ and $\mathrm{KH}_{2} \mathrm{PO}_{4}$ were replaced with agriculture fertilizers such as NPK (17:17:17), urea $\left(\mathrm{CH}_{4} \mathrm{~N}_{2} \mathrm{O}\right)$ and DAP (diammonium phosphate; $\left(\mathrm{NH}_{4}\right)_{2} \mathrm{HPO}_{4}$ + potash $\left(\mathrm{K}_{2} \mathrm{CO}_{3}\right)$ in different concentrations. The isolate of $H$. lacustris HPI-001 showed maximum growth at $1.2 \mathrm{mM} \mathrm{NPK}$, while the $H$. lacustris SAG-19a showed maximum growth at $1.5 \mathrm{mM}$. However, both the strains showed maximum astaxanthin content at $0.6 \mathrm{mM} \mathrm{NPK}$. The H. lacustris HPI-001 showed a maximum growth and astaxanthin content with $3.3 \mathrm{mM}$ and $4.9 \mathrm{mM}$ of urea, respectively, while H. lacustris SAG-19a showed maximum growth and astaxanthin accumulation with $3.3 \mathrm{mM}$ and $6.6 \mathrm{mM}$ of urea, respectively. The H. lacustris

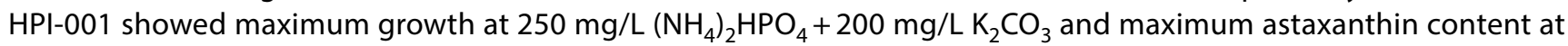
$150 \mathrm{mg} / \mathrm{L}\left(\mathrm{NH}_{4}\right)_{2} \mathrm{HPO}_{4}+100 \mathrm{mg} / \mathrm{L} \mathrm{K} \mathrm{CO}_{3}$, while the maximum growth in $\mathrm{H}$. lacustris SAG-19a was observed at $200 \mathrm{mg} / \mathrm{L}$ $\left(\mathrm{NH}_{4}\right)_{2} \mathrm{HPO}_{4}+150 \mathrm{mg} / \mathrm{L} \mathrm{K}_{2} \mathrm{CO}_{3}$, and the maximum astaxanthin content at $150 \mathrm{mg} / \mathrm{L}\left(\mathrm{NH}_{4}\right)_{2} \mathrm{HPO}_{4}+100 \mathrm{mg} / \mathrm{L} \mathrm{K} \mathrm{CO}_{3}$. The basal medium was also amended with the addition of commercial $\mathrm{NaHCO}_{3}$ wherein the maximum growth and content of astaxanthin in H. lacustris HPI-001 was at $0.6 \mathrm{mM}$ and $1.5 \mathrm{mM}$ of $\mathrm{NaHCO}_{3}$, respectively. The H. lacustris SAG-19a showed maximum growth and astaxanthin content at $1.5 \mathrm{mM}$ and $0.6 \mathrm{mM}$, respectively. Based on the investigation, a medium was formulated and named as modified $\mathrm{HPI}-001$ medium. The results of the present study suggest that commercial agricultural fertilizers may be used as excellent substitutes to enhance cell growth and astaxanthin production in $H$. lacustris.
\end{abstract}

Keywords Haematococcus lacustris · Carotenoids · Astaxanthin · Agriculture fertilizer

\section{Introduction}

Microalgae are photosynthetic microorganisms that can synthesize various organic biomolecules such as proteins, carbohydrates, lipids, pigments and vitamins from carbon dioxide $\left(\mathrm{CO}_{2}\right)$ [1]. These microalgae products have attracted intensive academic and industrial application including cosmetics, nutraceuticals, pharmaceuticals, aquaculture, food and biofuels [2-4]. The natural astaxanthin can be produced from microalgae, yeast, bacteria and various seafood including salmon, lobster, trout, red sea bream, arctic shrimp, crawfish, krill and fish eggs $[5,6]$. Various microorganisms such as Haematococcus lacustris, Chromochloris zofingiensis, red yeast Phaffia rhodozyma Electronic supplementary material The online version of this article (https://doi.org/10.1007/s42452-019-0543-z) contains
supplementary material, which is available to authorized users.

Nagaraj Subramani, nagalilly@gmail.com | ${ }^{1}$ Centre for Advanced Studies in Botany, University of Madras, Guindy Campus, Chennai 600025, India.

SN Applied Sciences (2019) 1:532 | https://doi.org/10.1007/s42452-019-0543-z

Received: 23 January 2019 / Accepted: 27 April 2019 / Published online: 7 May 2019 
and marine bacterium Agrobacterium aurantiacum can produce astaxanthin [7]. The $\mathrm{H}$. lacustris can accumulate a maximum astaxanthin of up to $4 \%$ dry weight under unfavorable environmental stress conditions [8-10].

The H. lacustris (Girod-Chantrans) Rostafinski 1875 is a green, motile, biflagellate microalga found in freshwater environments. It belongs to class Chlorophyceae, order Volvocales and family Haematococcaseae. Its life cycle consists of four stages such as macrozooids or zoospore, microzooids, palmella and aplanospore stages [11]. The macrozooid cells are between 8 and $20 \mu \mathrm{m}$ long with a distinct gelatinous extracellular gelatinous matrix of variable thickness, and these may be divided into 2-32 daughter cells by mitosis [9]. They form amorphous multilayered structures in the inner regions of the extracellular matrix or the primary cell wall as they develop into non-motile palmella and become resting vegetative cells [12]. When the culture is exposed to stress conditions such as the decrease in nutrients and the increase in light intensity and high salinity, the palmella stage transforms into the hematocyst aplanospore stage $[9,13]$. These microalgae can be usually found in temperate regions around the world and has been isolated from Europe, Africa, North America and Himachal Pradesh in India $[14,15]$ and also reported from Arctic region [16]. It is also found across various environmental and climatic conditions such as brackish water and on the rocks on seashore [16]. The astaxanthin-rich non-motile aplanospore coccoid cells have an exceptional tolerance to a wide range of adverse conditions [17-19]. The highly complex and dynamic composition of cell wall, photosynthetic apparatus reduction and cell dehydration allows $H$. lacustris to survive in hostile environment, but on the other hand presents an issue when $\mathrm{H}$. lacustris biomass has to be processed to extract valuable intracellular compounds such as astaxanthin [20].

The choice of culture medium for microalgae growth depends on the nutritional requirements that contribute toward the efficient growth and biomass production [21, 22]. The alternative sources of nutrients in the composition of culture media are urea, ammonium sulfate, water plants, swine manure and inorganic fertilizers (NPK) [23]. Nutrients are crucial in the growth and development of microalgae, influencing the physiological adaptation and biochemical composition of microalgae [15]. Nitrogen and phosphorus are the main elements that limit growth of microalgae, which usually depends on the physiological requirements of each nutrient [24]. The low $\mathrm{CO}_{2}$ concentration in the air is also limiting factor of photosynthesis in plants and algae [25]. There are several types of basic elements for growth of microalgae such as carbon, hydrogen, nitrogen, oxygen, phosphorus, magnesium, iron, sulfur and trace elements [26]. Potassium is a macroelement which is required for growth-related metabolic activities
[27]. The inorganic fertilizer is simple and may be used with alternative medium for microalgae, since they are widely available, dissolve easily, have a defined composition, high nitrogen and phosphorus rate, and maintain moderate $\mathrm{pH}$ in the medium $[28,29]$. The inorganic fertilizers such as NPK result in an efficient alternative medium for largescale laboratory growth of Chlorophyceaen members [30].

Astaxanthin $\left(\mathrm{C}_{40} \mathrm{H}_{52} \mathrm{O}_{4}, 3,3^{\prime}\right.$-dihydroxy- $\beta, \beta$-carotene$4,4^{\prime}$-dione), a keto-carotenoid, is considered as a "super antioxidant" which spans the cell membrane bilayer and significantly reduces the free radicals and oxidative stress in human body, thereby helping to maintain a healthy state $[5,31,32]$. It has the most effective natural antioxidant activity and is known to be 10-65 times higher than that of $\beta$-carotene, canthaxanthin, zeaxanthin, lutein and vitamin $C$, and is 100 times more effective than a-tocopherol [11, 33]. It has wide range of applications in cosmetics, foods, nutraceuticals, aquaculture and pharmaceuticals industries $[11,34,35]$. Astaxanthin is also used as a promising therapeutic agent against atherosclerosis, cancers, hypertension, diabetes, cardiovascular diseases and several neurological diseases (e.g., Alzheimer's disease) because it is known to cross the blood-brain barrier and enables to provide antioxidant benefits beyond that barrier $[36,37]$. Astaxanthin is also currently used in the prevention and control of many pathological conditions involving low oxidation and inflammation $[38,39]$.

In the present study, a new strain of H. lacustris HPI-001 was isolated from Himachal Pradesh, India, and another strain $H$. lacustris SAG-19a culture was obtained from Sammlung von Kulturen, Pflanzen Physiologisches Institut, University of Gottingen, Gottingen, Germany. The latter was treated as control, and its adaptation to laboratory conditions was investigated. The two strains were grown in Bold basal medium (BBM) [40] amended with the addition of commercial fertilizers such as N:P:K (17:17:17), $\mathrm{CH}_{4} \mathrm{~N}_{2} \mathrm{O}$ and $\left(\mathrm{NH}_{4}\right)_{2} \mathrm{HPO}_{4}+\mathrm{K}_{2} \mathrm{CO}_{3}$ and its influence on growth and astaxanthin production were evaluated.

\section{Materials and methods}

\subsection{Isolation of $\boldsymbol{H}$. lacustris HPI-001}

The water samples were collected from Palampur in March 2013. Palampur ( $32^{\circ} \mathrm{N}$ latitude; $76^{\circ} \mathrm{E}$ longitude) is a town in the state of Himachal Pradesh in India and is $1325 \mathrm{ft}$. above sea level with average annual temperature of $19^{\circ} \mathrm{C}$ and average annual rainfall of $250 \mathrm{~cm}$ and above. The water sample from each aquatic site was collected and stored in plastic bottles. The samples were inoculated in BBM at $25 \pm 1{ }^{\circ} \mathrm{C}$, under $30 \mu \mathrm{E} \mathrm{m}^{-2} \mathrm{~s}^{-1}$ light irradiations and a photoperiod of 12/12 (light/dark). The 
cultures were thoroughly mixed manually twice a day, and the experiment was conducted at laboratory conditions. The cells of H. lacustris HPI-001 were isolated and prepared unialgal cultures by serial dilution followed by streak plate technique on $2 \%$ agar in BBM. The cells were identified based on morphological and molecular studies. H. lacustris SAG-19a was retrieved from Gottingen Culture Collection, Germany.

\subsection{Composition of culture medium}

The two strains of $\mathrm{H}$. lacustris were cultured in the BBM in which the components, sodium nitrate $\left(\mathrm{NaNO}_{3}\right)$, dibasic potassium phosphate trihydrate $\left(\mathrm{K}_{2} \mathrm{HPO}_{4} \cdot 3 \mathrm{H}_{2} \mathrm{O}\right)$ and potassium phosphate monobasic $\left(\mathrm{KH}_{2} \mathrm{PO}_{4}\right)$, were replaced with different concentrations of commercial fertilizers such as N:P:K (17:17:17), urea $\left(\mathrm{CH}_{4} \mathrm{~N}_{2} \mathrm{O}\right)$, diammonium phosphate $\left(\left(\mathrm{NH}_{4}\right)_{2} \mathrm{HPO}_{4}\right)$ and potassium carbonate $\left(\mathrm{K}_{2} \mathrm{CO}_{3}\right)$ (Shri Sai Gopal Agrotech Pvt. Ltd., Karnataka, India). The other chemicals of the medium were obtained from Sisco Research Laboratories Pvt. Ltd., Mumbai (Table 3). The growth and astaxanthin production in two test organisms were also recorded in basal medium added with different concentrations $(0.3,0.6,0.9,1.2,1.5$ and $1.8 \mathrm{mM})$ of commercial sodium bicarbonate $\left(\mathrm{NaHCO}_{3}\right)$ fertilizers (Table 1). The growth and astaxanthin production of $\mathrm{H}$. lacustris HPI-001 and the $H$. lacustris SAG-19a in modified Bold basal medium (3 N-BBM +V) and formulated modified HPI-001 medium was compared (Table 2).

Table 1 Medium composition

\begin{tabular}{|c|c|}
\hline Chemical components & $\mathrm{mg} / \mathrm{L}$ \\
\hline $\mathrm{N}: P: K(17: 17: 17)^{a}$ & 2500 \\
\hline $\mathrm{CH}_{4} \mathrm{~N}_{2} \mathbf{O}^{\mathrm{a}}$ & 13,000 \\
\hline $\mathrm{CaCl}_{2} \cdot 3 \mathrm{H}_{2} \mathrm{O}$ & 2500 \\
\hline $\mathrm{MgSO}_{4} \cdot 7 \mathrm{H}_{2} \mathrm{O}$ & 2500 \\
\hline $\mathrm{NaHCO}_{3}^{a}$ & 2500 \\
\hline$\left(\mathrm{NH}_{4}\right)_{2} \mathrm{HPO}_{4}^{\mathrm{a}}$ & 5000 \\
\hline $\mathrm{K}_{2} \mathrm{CO}_{3}^{\mathrm{a}}$ & 7500 \\
\hline $\mathrm{NaCl}$ & 2500 \\
\hline EDTA (with $\mathrm{Na}_{2}$ ) & 750 \\
\hline $\mathrm{FeCl}_{3} \cdot 6 \mathrm{H}_{2} \mathrm{O}$ & 97 \\
\hline $\mathrm{MnCl}_{2} \cdot 4 \mathrm{H}_{2} \mathrm{O}$ & 41 \\
\hline $\mathrm{ZnCl} \cdot 6 \mathrm{H}_{2} \mathrm{O}$ & 5 \\
\hline $\mathrm{CoCl}_{2} \cdot 6 \mathrm{H}_{2} \mathrm{O}$ & 2 \\
\hline $\mathrm{Na}_{2} \mathrm{MoO}_{4} \cdot 2 \mathrm{H}_{2} \mathrm{O}$ & 4 \\
\hline
\end{tabular}

All the medium components dissolved in $1 \mathrm{~L}$ of distilled water $\mathrm{pH}$ of the medium is 7.5

${ }^{\text {a }}$ Replaced commercial fertilizers in basal medium (3N-BBM+V)
Table 2 Formulated commercial modified HPI-001 medium

\subsection{Maintenance and study of algal culture}

The two strains of $\mathrm{H}$. lacustris were grown under autotrophic condition, in a photoperiod of $12 / 12 \mathrm{~h}$ (light/ dark) in liquid $\mathrm{BBM}$ and maintained at $25 \pm 1{ }^{\circ} \mathrm{C}$, under $30 \mu \mathrm{Em}-2 \mathrm{~s}-1$ light intensity provided by warm white Philips set of lamps (36 W; $4 \mathrm{ft}$ Philips Trulite, made in India), the light intensity was measured by using lux meter (TES 1331, Taiwan), and the culture parameters periodically were measured for 30 days. The experiments were conducted with sterilized 250-mL Erlenmeyer conical flasks. Ten milliliters each of pure culture was taken at exponential growth phase (7 days), and this initial culture density of $2.0 \times 10^{4}$ cells $/ \mathrm{mL}$ was inoculated into $90 \mathrm{~mL}$ of sterilized BBM medium under aseptic condition. The growth parameters such as cell number, pigments such as chlorophyll $a(\mathrm{Chl} a)$ and chlorophyll $b$ $(\mathrm{Chl} b)$, total carotenoids and astaxanthin contents were recorded at every 5-day interval during the study period. Monoalgal culture of the algae was used in the following experiments.

\subsubsection{Cell count}

"Neubauer" hemocytometer (REF: 0303 212, Neubauer Improved Bright-Line, HBG, Germany) was used for the purpose. The mean of the cell numbers recorded in four chambers was calculated and expressed as multiples of $10^{4}$ cells $/ \mathrm{mL}$. 


\subsubsection{Growth curve}

Growth curves were plotted with cell count values (multiples of $10^{4}$ cells $/ \mathrm{mL}$ ) against respective days on which the cell count was measured.

\subsubsection{Determination of specific growth rate $(\mu)$, division rate $(K)$ and generation time (DT)}

The specific growth rate implies the number of generation or the number of doublings that occur per unit of time in an exponential growth culture. The specific growth rate was determined using the following equation [41]: $\mu=\ln$ $(N t / N 0) /(T-t) ; N t=$ no of cells at the end of the log phase; $N O=$ no of cells at the start of $\log$ phase; $T=$ final day of log phase; $t=$ starting day of log phase, if $T$ expressed in days from the growth rate $(\mu)$ can be converted to $K=\mu / 1 \mathrm{n}$ (2).

\subsubsection{Extraction and estimation of pigments}

Five milliliters of culture was centrifuged at $5000 \mathrm{rpm}$ for $10 \mathrm{~min}$, and the supernatant was discarded. The algal pellet was added with $5 \mathrm{~mL}$ of $100 \%$ acetone and macerated using pestle and mortar wrapped with black paper and kept overnight at $4{ }^{\circ} \mathrm{C}$. The sample was centrifuged (R-8C; Remi Instruments Ltd, Mumbai, India) at $5000 \mathrm{rpm}$ for $10 \mathrm{~min}$, supernatant was collected, and the absorbance was measured at $661.6 \mathrm{~nm}, 644.8 \mathrm{~nm}, 470 \mathrm{~nm}$ and $490 \mathrm{~nm}$ wavelengths in Ultrospec 1100 pro UV-visible spectrophotometer (Amersham Bioscience, Germany) in standard quartz cuvette $(190-2500 \mathrm{~nm})$, path length $10 \mathrm{~mm}$. The chlorophyll and total carotenoid contents were calculated using Lichtenthaler equations [42]. The amount of astaxanthin was determined from the acetone extract measured at $490 \mathrm{~nm}$. The per unit volume of astaxanthin concentration ( $\mathrm{mg} / \mathrm{L})$ was calculated by using the methods [43].

$$
\begin{aligned}
& \text { Chl } a(\mathrm{mg} / \mathrm{L})=11.24 \times A_{661.6}-2.404 \times A_{644.8} \\
& \text { Chl } b(\mathrm{mg} / \mathrm{L})=20.13 \times A_{644.8}-4.19 \times A_{661.6} \\
& \text { Total carotenoids }(\mathrm{mg} / \mathrm{L}) \\
& \quad=\frac{1000 \times A_{470}-1.9 \times \mathrm{Chl} a-63.14 \times \mathrm{Chl} b}{214}
\end{aligned}
$$

Astaxanthin $(\mathrm{mg} / \mathrm{L})=4.5 \times A_{490} \times \mathrm{Va} / \mathrm{Vb}$

where $A=$ absorbance; $V a=$ volume of extracts; $V b=$ volume of culture sample.

\subsubsection{Statistical analysis}

All the experiments were carried out in triplicate and expressed as mean \pm standard errors. The graphs were prepared by Graph Pad Prism 6 software.

\section{Results}

\subsection{Identification of isolates}

The different growth phase of the microalga $H$. lacustris $\mathrm{HPI}-001$ was identified through microscopic examination and observed the cell size and shapes such as spherical, ellipsoidal or pear shape, in addition to which the cells clearly showed two flagella of equal length emerging from the anterior end, and a cup-shaped chloroplast with numerous, scattered pyrenoids. Further the culture was confirmed through molecular studies (18S rRNA) and identified as H. lacustris HPI-001, and the molecular data were submitted in GenBank and received accession number (KT285940). Under unfavorable conditions, the macrozooids get transition into the coccoid vegetative cell state by loosing flagella (LABOMED VISION 2000, $40 \times$ magnifications). When the cultures were exposed to stress conditions, the volume of the cell increased with a diameter of over $40 \mu \mathrm{m}$ and the cell wall became resistant to the harsh conditions in which it was present. The maturation cyst aplanospore cells were accompanied by the enhancement of carotenoids biosynthesis and a gradual change in cell color to red. During optimal growth conditions, the daughter cells were released from the cystic cells and then vegetative cells regenerated from the daughter cells. Both the strains were maintained at Algal Culture Collection, Centre for Advanced Studies in Botany, University of Madras, Tamil Nadu, India (Figs. 1, 2).

\subsection{Effect of different concentrations of commercial N:P:K (17:17:17)}

The two strains of $H$. lacustris were grown at different concentrations of commercial NPK (17:17:17). The H. lacustris HPI-001 showed maximum cell number of $47 \times 10^{4}$ cells/ $\mathrm{mL}$ in $1.2 \mathrm{mM}$ of commercial NPK on 15th day of culture. At $1.2 \mathrm{mM}$, a specific growth rate of 0.117 day $^{-1}$, division rate of 0.169 day $^{-1}$ and generation time of 5.931 day were recorded. The maximum concentration of $\mathrm{Chl} a$ $(7.13 \mathrm{mg} / \mathrm{L})$ and $\mathrm{Chl} b(3.57 \mathrm{mg} / \mathrm{L})$ was recorded on 20 th day at $1.2 \mathrm{mM}$ NPK. The $H$. lacustris SAG-19a showed a maximum cell number of $42 \times 10^{4}$ cells $/ \mathrm{mL}$, and a maximum concentration of $\mathrm{Chl} a(6.25 \mathrm{mg} / \mathrm{L})$ and $\mathrm{Chl}$ $b(3.13 \mathrm{mg} / \mathrm{L})$ on 20 th day of $1.5 \mathrm{mM} \mathrm{NPK}$. The increase in growth was $11 \%$, and pigments $\mathrm{Chl} a 14 \%$ and $\mathrm{Chl} b$ were $10 \%$ which was more than that of $H$. lacustris SAG19a. The alga $\mathrm{H}$. lacustris $\mathrm{HPI}-001$ accumulated maximum total carotenoids $(22.33 \mathrm{mg} / \mathrm{L})$ and astaxanthin content (17.94 mg/L) in 0.6 mM NPK on 30th day (Fig. 3). The $H$. lacustris SAG-19a exhibited maximum content of total 
Fig. 1 Light microscopic image of isolate H. lacustris HPI-001 cells in life cycle in laboratory conditions. a Biflagellated motile cells (macrozooids); $\mathbf{b}$ non-motile green vegetative cells (palmella); c astaxanthin accumulating palmella cell in transition to aplanospores; $\mathbf{d}$ astaxanthin accumulated aplanospore cell. Scale bar: $10 \mu \mathrm{m}$
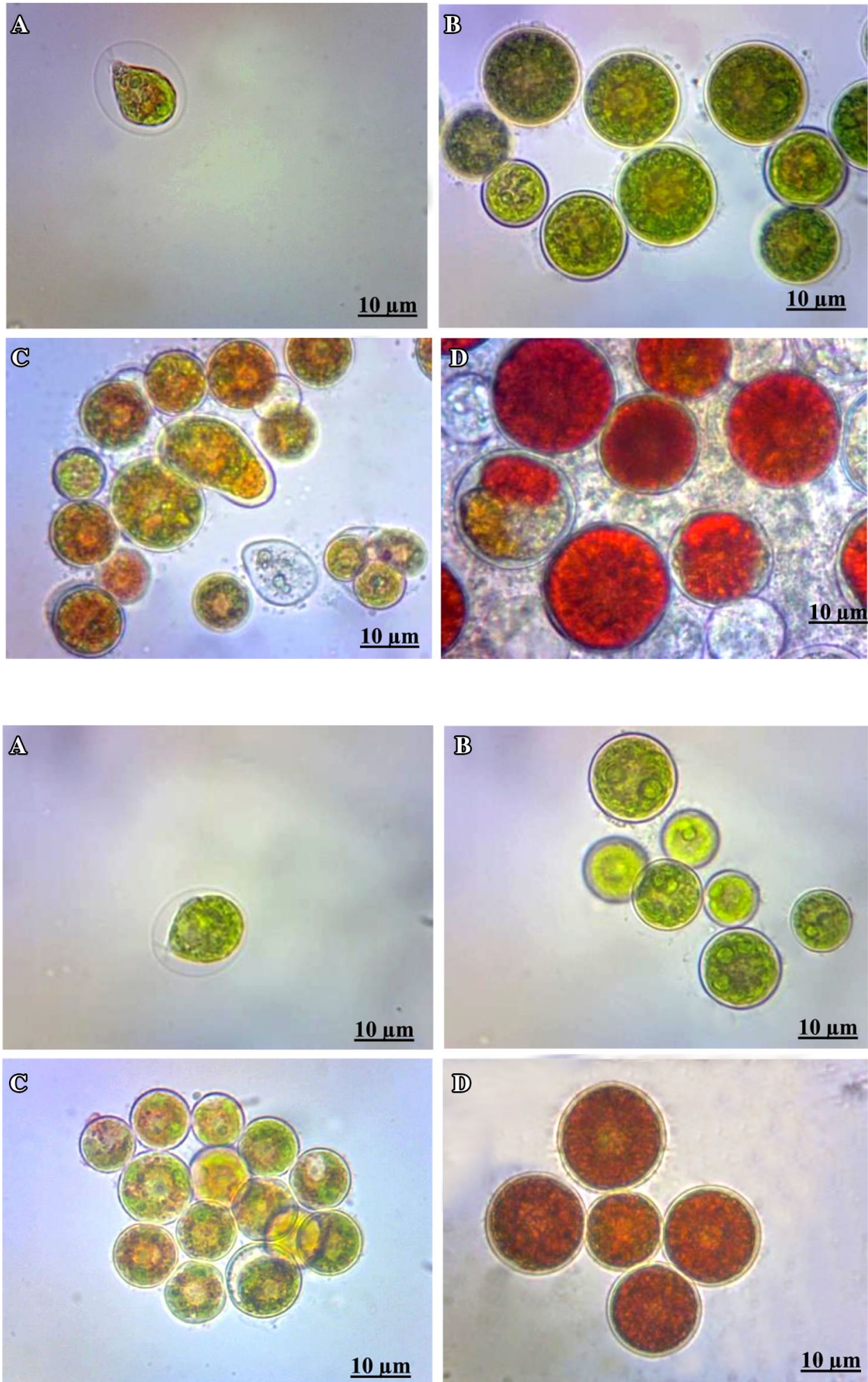

$\underline{10 \mu m}$
Fig. 2 Light microscopic image of H. lacustris SAG-19a cells in life cycle in laboratory conditions. a Biflagellated motile cells (macrozooids); $\mathbf{b}$ non-motile green vegetative cells (palmella); c astaxanthin accumulating palmella cell in transition to aplanospores; $\mathbf{d}$ astaxanthin accumulated aplanospore cell. Scale bar: $10 \mu \mathrm{m}$

\subsection{Effect of different concentrations of $\mathrm{CH}_{4} \mathrm{~N}_{2} \mathrm{O}$}

The alga $\mathrm{H}$. lacustris $\mathrm{HPI}-001$ showed maximum cell number of $41 \times 10^{4}$ cells $/ \mathrm{mL}$ on 15 th day in $3.3 \mathrm{mM}$ of $\mathrm{CH}_{4} \mathrm{~N}_{2} \mathrm{O}$. At $3.3 \mathrm{mM}$ of $\mathrm{CH}_{4} \mathrm{~N}_{2} \mathrm{O}$, the specific growth rate, division rate 

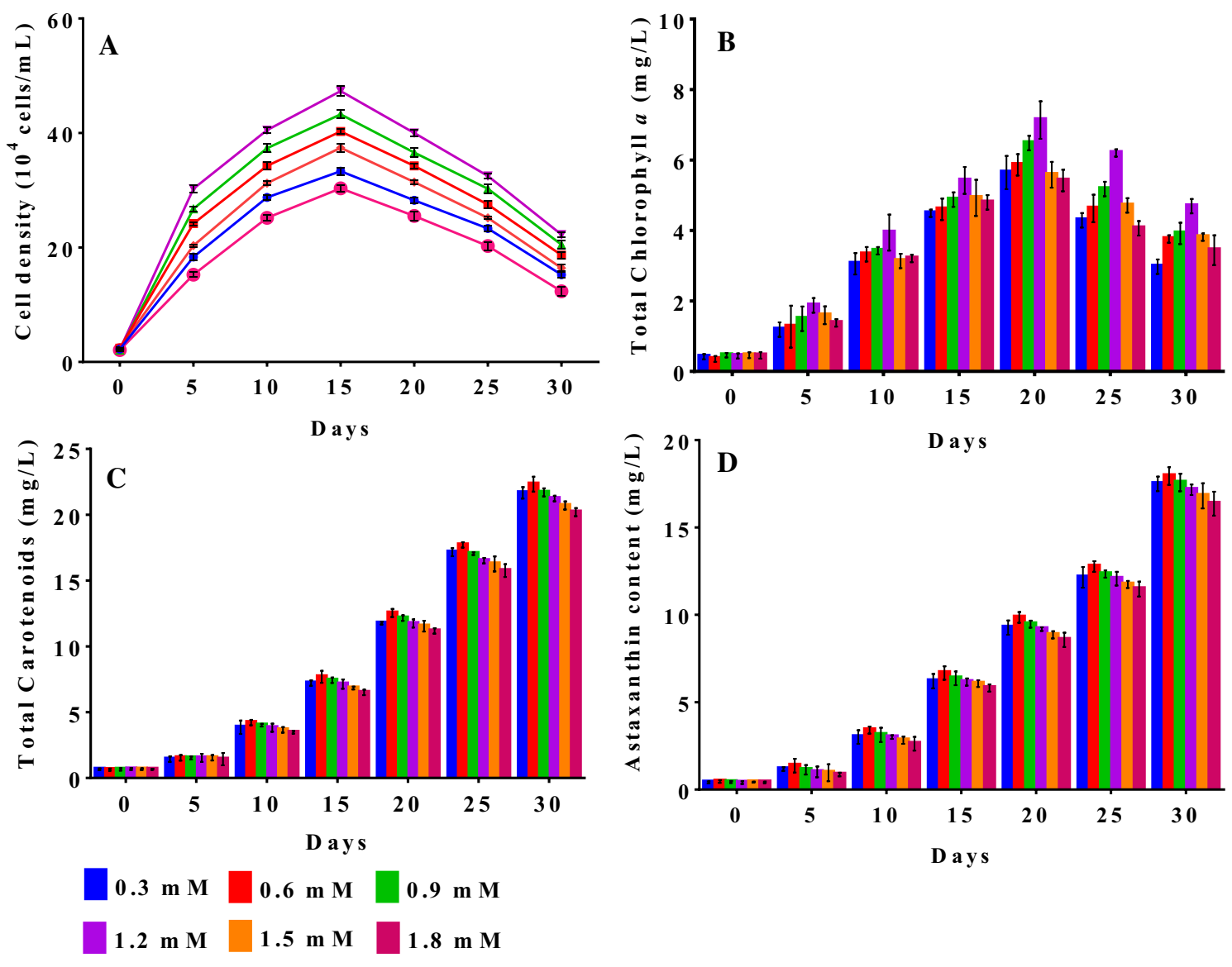

Fig. 3 Effect of different concentrations of commercial agriculture fertilizer N:P:K (17:17:17) $(0.3,0.6,0.9,1.2,1.5$ and $1.8 \mathrm{mM})$ on a cell number (a), chlorophyll a (b), total carotenoids $(\mathbf{c})$ and astaxanthin

and generation time were 0.197 day $^{-1}, 0.284$ day $^{-1}$ and 3.515 day, respectively. The maximum synthesis of pigments $\mathrm{Chl} a(8.26 \mathrm{mg} / \mathrm{L})$ and $\mathrm{Chl} b(4.13 \mathrm{mg} / \mathrm{L})$ was on 15 th day in $3.3 \mathrm{mM} \mathrm{CH}_{4} \mathrm{~N}_{2} \mathrm{O}$. The $\mathrm{H}$. lacustris SAG-19a exhibited maximum growth of $32 \times 10^{4}$ cells $/ \mathrm{mL}$ in $3.3 \mathrm{mMCH}_{4} \mathrm{~N}_{2} \mathrm{O}$ on 15th day. The increase in growth (28\%), pigments $\mathrm{Chl} a(14 \%)$ and $\mathrm{Chl} b(13 \%)$ was more than that of H. lacustris SAG-19a. The maximum accumulation of total carotenoids in $\mathrm{H}$. lacustris $\mathrm{HPI}-001$ was $18.50 \mathrm{mg} / \mathrm{L}$, and astaxanthin content was $15.19 \mathrm{mg} / \mathrm{mL}$ at $4.9 \mathrm{mM}$ of $\mathrm{CH}_{4} \mathrm{~N}_{2} \mathrm{O}$ on 25 th day (Fig. 4). The $H$. lacustris SAG-19a showed a maximum concentration of $15.97 \mathrm{mg} / \mathrm{L}$ total carotenoids and $12.84 \mathrm{mg} / \mathrm{L}$ astaxanthin content at $6.6 \mathrm{mM} \mathrm{CH}_{4} \mathrm{~N}_{2} \mathrm{O}$ on 25th day (supplementary data S2). The increment of total carotenoids (15\%) and astaxanthin content (18\%) was more than H. lacustris SAG-19a.

\subsection{Effect of different concentrations of $\left(\mathrm{NH}_{4}\right)_{2} \mathrm{HPO}_{4}$ and $\mathrm{K}_{2} \mathrm{CO}_{3}$}

Under different concentrations of $\left(\mathrm{NH}_{4}\right)_{2} \mathrm{HPO}_{4}+\mathrm{K}_{2} \mathrm{CO}_{3}$, the alga $\mathrm{H}$. lacustris $\mathrm{HPI}-001$ exhibited the maximum cell

content (d) isolate of $\mathrm{H}$. lacustris HPI-001 at different intervals in laboratory conditions

number of $35 \times 10^{4}$ cells $/ \mathrm{mL}$ in the medium with $250 \mathrm{mg} / \mathrm{L}$ $\left(\mathrm{NH}_{4}\right)_{2} \mathrm{HPO}_{4}+200 \mathrm{mg} / \mathrm{L} \mathrm{K}_{2} \mathrm{CO}_{3}$ on 20th day of culture.

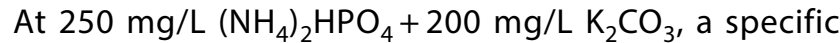
growth rate of 0.178 day $^{-1}$, division rate of 0.257 day $^{-1}$ and generation time of 3.893 day were observed. The maximum synthesis of pigments recorded was $7.11 \mathrm{mg} / \mathrm{L}$ $\mathrm{Chl} a$ and $3.56 \mathrm{mg} / \mathrm{L} \mathrm{Chl} b$ on 20th day at $250 \mathrm{mg} / \mathrm{L}$ $\left(\mathrm{NH}_{4}\right)_{2} \mathrm{HPO}_{4}+200 \mathrm{mg} / \mathrm{L} \mathrm{K}_{2} \mathrm{CO}_{3}$. The maximum growth in $H$. lacustris SAG-19a was recorded as $30 \times 10^{4}$ cells $/ \mathrm{mL}$ in the medium with $200 \mathrm{mg} / \mathrm{L}\left(\mathrm{NH}_{4}\right)_{2} \mathrm{HPO}_{4}+150 \mathrm{mg} / \mathrm{L} \mathrm{K}_{2} \mathrm{CO}_{3}$ on 20th day. Similarly, the maximum concentration of $\mathrm{Chl}$ $a$ was $6.76 \mathrm{mg} / \mathrm{L}$ and $\mathrm{Chl} b$ was $3.39 \mathrm{mg} / \mathrm{L}$ at $200 \mathrm{mg} / \mathrm{L}$ $\left(\mathrm{NH}_{4}\right)_{2} \mathrm{HPO}_{4}+150 \mathrm{mg} / \mathrm{L} \mathrm{K}_{2} \mathrm{CO}_{3}$ on 20th day. The increase in growth (16\%) and pigments $\mathrm{Chl} a(5 \%)$ and $\mathrm{Chl} b(5 \%)$ was more than that of $H$. lacustris SAG-19a. The H. lacustris $\mathrm{HPI}-001$ accumulated a maximum total carotenoids of $15.99 \mathrm{mg} / \mathrm{L}$ and astaxanthin content of $12.69 \mathrm{mg} / \mathrm{L}$ at $150 \mathrm{mg} / \mathrm{L}\left(\mathrm{NH}_{4}\right)_{2} \mathrm{HPO}_{4}+100 \mathrm{mg} / \mathrm{L} \mathrm{K}_{2} \mathrm{CO}_{3}$ on 25th day (Fig. 5), while the H. lacustris SAG-19a accumulated a maximum total carotenoids of $13.88 \mathrm{mg} / \mathrm{L}$ and astaxanthin content of $11.99 \mathrm{mg} / \mathrm{L}$ at $150 \mathrm{mg} / \mathrm{L}\left(\mathrm{NH}_{4}\right)_{2} \mathrm{HPO}_{4}+100 \mathrm{mg} / \mathrm{L}$ 

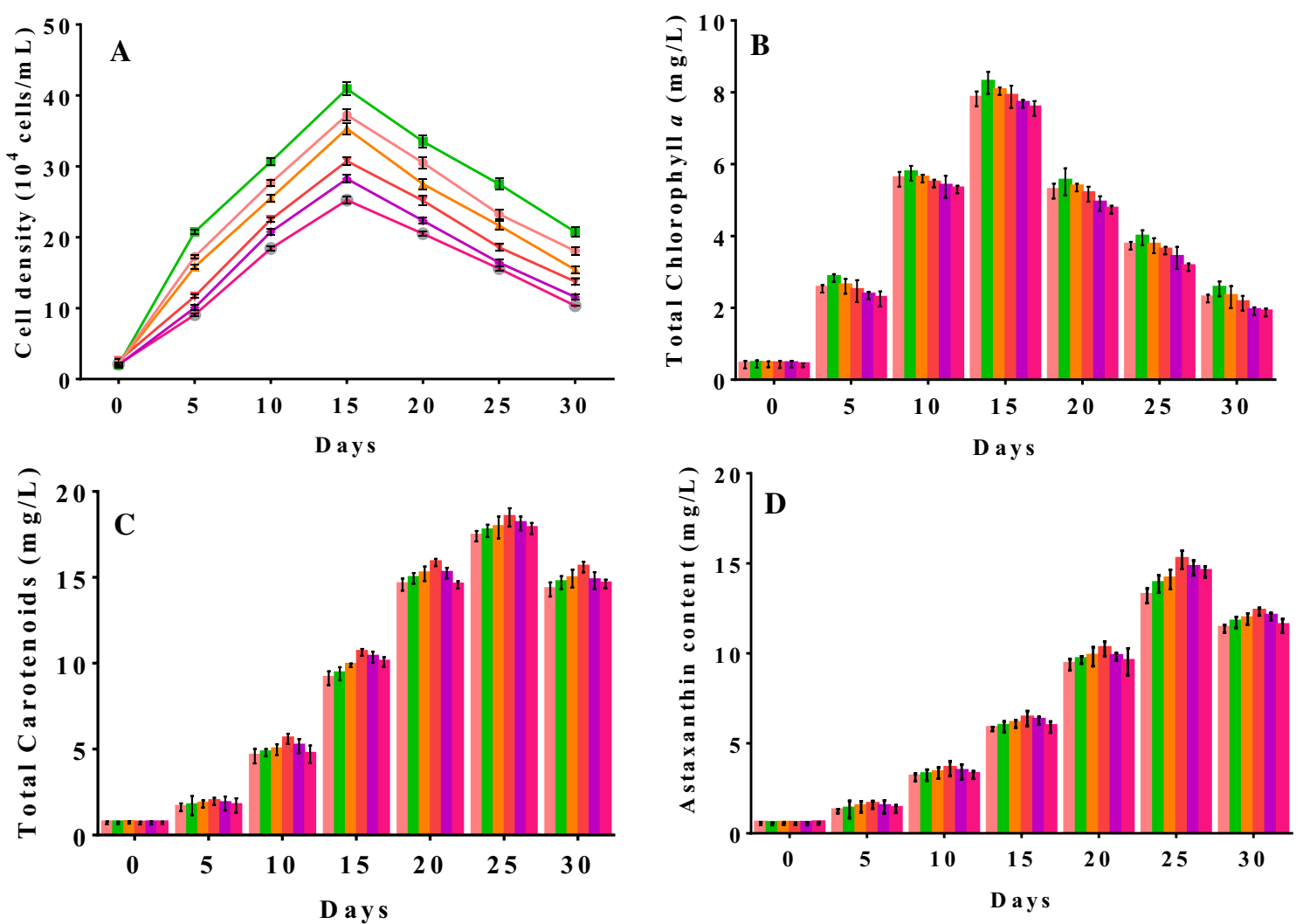
$1.6 \mathrm{~m} \mathrm{M}$
$3.3 \mathrm{~m} \mathrm{M}$
$4.3 \mathrm{~m} \mathrm{M}(\mathrm{Control})$
$4.9 \mathrm{~m} \mathrm{M}$
$6.6 \mathrm{~m} \mathrm{M}$
$8.3 \mathrm{~m} \mathrm{M}$

Fig. 4 Effect of different concentration of commercial agriculture fertilizers $\mathrm{CH}_{4} \mathrm{~N}_{2} \mathrm{O}$ on a cell number (a), chlorophyll a (b), total carotenoids (c) and astaxanthin content (d) isolate of $\mathrm{H}$. lacustris HPI-001 at different intervals in laboratory conditions

$\mathrm{K}_{2} \mathrm{CO}_{3}$ on 30th day (supplementary data $\mathrm{S} 3$ ). The increase in total carotenoids (15\%) and astaxanthin content (10\%) was more than control of $H$. lacustris SAG-19a.

\subsection{Effect of different concentrations of $\mathrm{NaHCO}_{3}$}

The H. lacustris HPI-001 exhibited a maximum cell number of $51 \times 10^{4}$ cells $/ \mathrm{mL}$ at $0.6 \mathrm{mM}$ commercial $\mathrm{NaHCO}_{3}$ in 20 days. At $0.6 \mathrm{mM}$ of $\mathrm{NaHCO}_{3}$, a specific growth rate of 0.184 day $^{-1}$, division rate of 0.266 day $^{-1}$ and generation time of 3.759 day were observed. The maximum synthesis of pigments, $\mathrm{Chl} a(9.52 \mathrm{mg} / \mathrm{L})$ and $\mathrm{Chl} b(4.76 \mathrm{mg} / \mathrm{L})$, was in $0.6 \mathrm{mM}$ of $\mathrm{NaHCO}_{3}$ on 20th day. The H. lacustris SAG-19a showed a maximum growth of $45 \times 10^{4}$ cells/ $\mathrm{mL}$ at $1.5 \mathrm{mM} \mathrm{NaHCO}_{3}$ on 20th day. The maximum concentration of $\mathrm{Chl} a(8.81 \mathrm{mg} / \mathrm{L})$ and $\mathrm{Chl} b(4.40 \mathrm{mg} / \mathrm{L})$ was in $0.6 \mathrm{mM} \mathrm{NaHCO}_{3}$ on 20th day. The increment of growth (13\%) and pigments $\mathrm{Chl} a(8 \%)$ and $\mathrm{Chl} b(8 \%)$ was more than that of $H$. lacustris SAG-19a. The maximum accumulation of total carotenoids in the isolate of H. lacustris HPI-001 was $19.24 \mathrm{mg} / \mathrm{L}$, and astaxanthin content was $15.53 \mathrm{mg} / \mathrm{L}$ in $1.5 \mathrm{mM}$ of $\mathrm{NaHCO}_{3}$ on 25 th day of culture (Fig. 6). The strain H. lacustris SAG-19a synthesized maximum total carotenoids of $16.89 \mathrm{mg} / \mathrm{L}$ and astaxanthin content of $13.71 \mathrm{mg} / \mathrm{L}$ in $0.6 \mathrm{mM}$ of $\mathrm{NaHCO}_{3}$ on 30th day (supplementary data S4). The increase in total carotenoids (13\%) and total astaxanthin (13\%) was more compared to H. lacustris SAG-19a.

\subsection{Comparative study of the two strains of $H$. lacustris grown in modified $3 \mathrm{~N}-\mathrm{BBM}+\mathrm{V}$ medium and formulated modified HPI-001 medium}

The isolate $\mathrm{H}$. lacustris HPI-001 grown in two different media tested showed a maximum growth of $43 \times 10^{4}$ cells/ $\mathrm{mL}$ in formulated modified HPI-001 medium on 20th day. The alga grown in formulated modified HPI-001 medium showed a specific growth rate of $0.162 \mathrm{day}^{-1}$, division rate of 0.233 day $^{-1}$ and generation time of 4.284 day. The alga synthesized $8.68 \mathrm{mg} / \mathrm{L} \mathrm{Chl} a$ and $5.12 \mathrm{mg} / \mathrm{L} \mathrm{Chl} b$ on 20th day, and $25.51 \mathrm{mg} / \mathrm{L}$ total carotenoids and $22.21 \mathrm{mg} / \mathrm{L}$ 

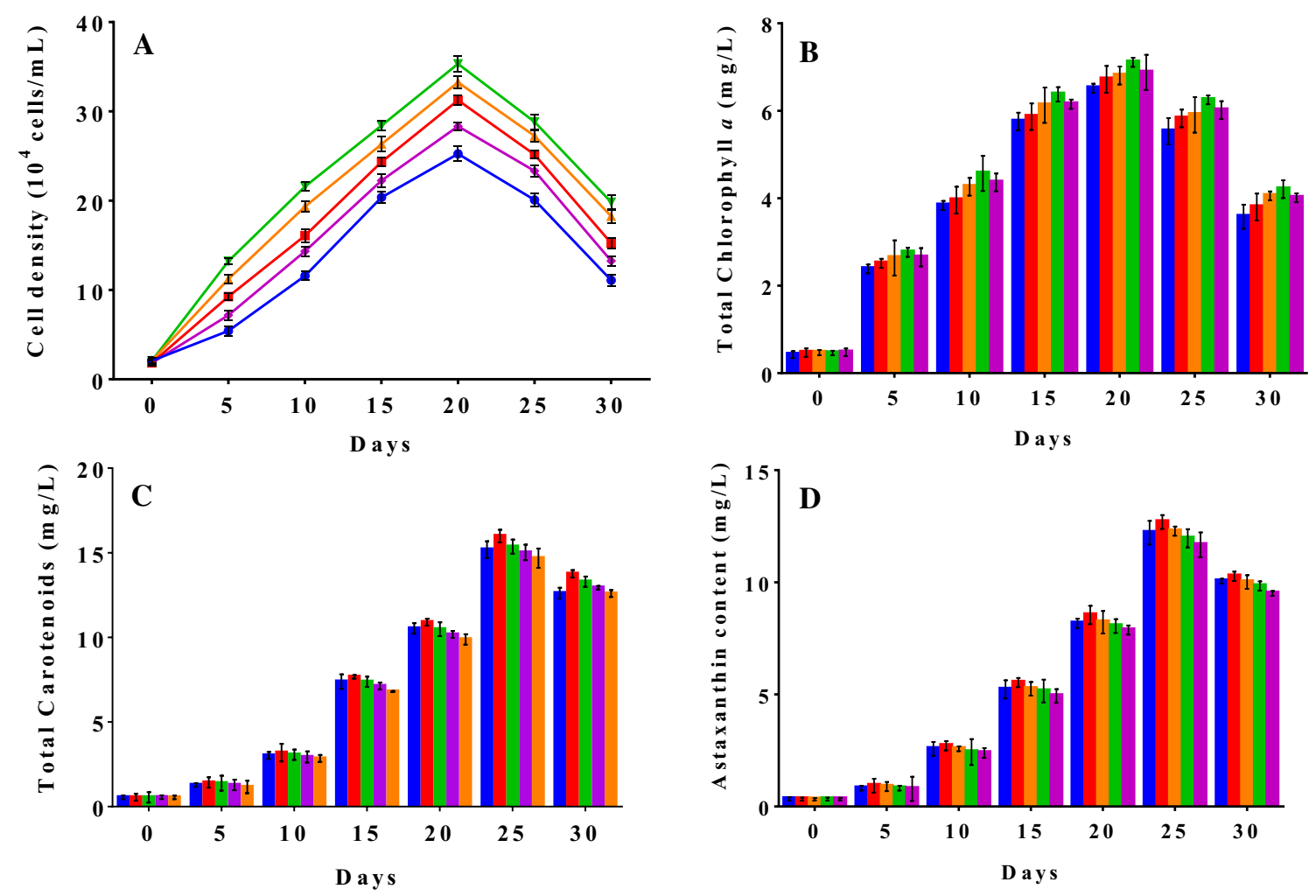

$100+50 \mathrm{mg} \quad 150+100 \mathrm{mg} \quad 200+150 \mathrm{mg}$ (Control)
$250+200 \mathrm{mg} \quad 300+250 \mathrm{mg}$

Fig. 5 Effect of different concentration of commercial agriculture fertilizers $\left(\mathrm{NH}_{4}\right)_{2} \mathrm{HPO}_{4}+\mathrm{K}_{2} \mathrm{CO}_{3}$ on a cell number (a), chlorophyll a (b), total carotenoids (c) and astaxanthin content (d) isolate of $\mathrm{H}$. lacustris HPI-001 at different intervals in laboratory conditions

astaxanthin content on 30th day in formulated modified HPI-001 medium (Fig. 7). The H. lacustris HPI-001 showed a maximum growth of $37 \times 10^{4}$ cells $/ \mathrm{mL}$ in modified $3 \mathrm{~N}-\mathrm{BBM}+\mathrm{V}$ medium on 20th day. The maximum synthesis of pigments $\mathrm{Chl} a(7.44 \mathrm{mg} / \mathrm{L}), \mathrm{Chl} b(3.72 \mathrm{mg} / \mathrm{L})$, total carotenoids $(22.88 \mathrm{mg} / \mathrm{L})$ and astaxanthin content $(20.45 \mathrm{mg} / \mathrm{L})$ was on 20th and 30th day in modified $3 \mathrm{~N}-\mathrm{BBM}+\mathrm{V}$ medium. In case of $H$. lacustris SAG-19a, the maximum cell number of $40 \times 10^{4}$ cells $/ \mathrm{mL}$ in formulated modified HPI-001 medium was on 20th day. The alga grown in formulated modified HPI-001 medium showed a specific growth rate of 0.184 day $^{-1}$, division rate of 0.266 day $^{-1}$ and generation time of 3.763 day. The maximum concentration of pigments $\mathrm{Chl} a(7.22 \mathrm{mg} / \mathrm{L})$ and $\mathrm{Chl} b(4.36 \mathrm{mg} / \mathrm{L})$ was on 20 th day, and maximum accumulation of total carotenoids $(23.59 \mathrm{mg} / \mathrm{L})$ and astaxanthin content $(20.10 \mathrm{mg} / \mathrm{L}$ ) was on 30th day in formulated modified HPI-001 medium (Table 3). The H. lacustris SAG-19a showed maximum growth of $35 \times 10^{4}$ cells $/ \mathrm{mL}$ on 20 th day of modified $3 \mathrm{~N}-\mathrm{BBM}+\mathrm{V}$ medium. The maximum synthesis of Chl $a(6.50 \mathrm{mg} / \mathrm{L}), \mathrm{Chl} b(3.25 \mathrm{mg} / \mathrm{L})$, total carotenoids $(20.55 \mathrm{mg} / \mathrm{L})$ and astaxanthin content $(18.25 \mathrm{mg} / \mathrm{L})$ was on 20th and 30th day in modified $3 \mathrm{~N}-\mathrm{BBM}+\mathrm{V}$ medium (supplementary data S5). The increase in growth (8\%), Chl $a$ (20\%), Chl $b(17 \%)$, total carotenoids (8\%) and astaxanthin content (10\%) was more than that of H. lacustris SAG-19a.

\section{Discussion}

$H$. lacustris is a photosynthetic green microalga that can produce astaxanthin in cells. In general, astaxanthin production from $\mathrm{H}$. lacustris is accomplished through a twostage cultivation process including vegetative (green) and aplanospore (red) stages $[44,45]$. The accumulation of astaxanthin is affected by environmental stress factors such as light, temperature, $\mathrm{pH}$, salt concentration and nutritional stresses [11]. However, some factors limit outdoor production such as light intensity and temperature. Therefore, the induction of high astaxanthin accumulation with nutrition is a significant option. Though, including the neutral $\mathrm{pH}$, neutral to the moderately basic range was recognized as the most favorable and suitable condition for the fungal contaminant to infect the algae cells [46], the present cultures were found to be devoid of any fungal 

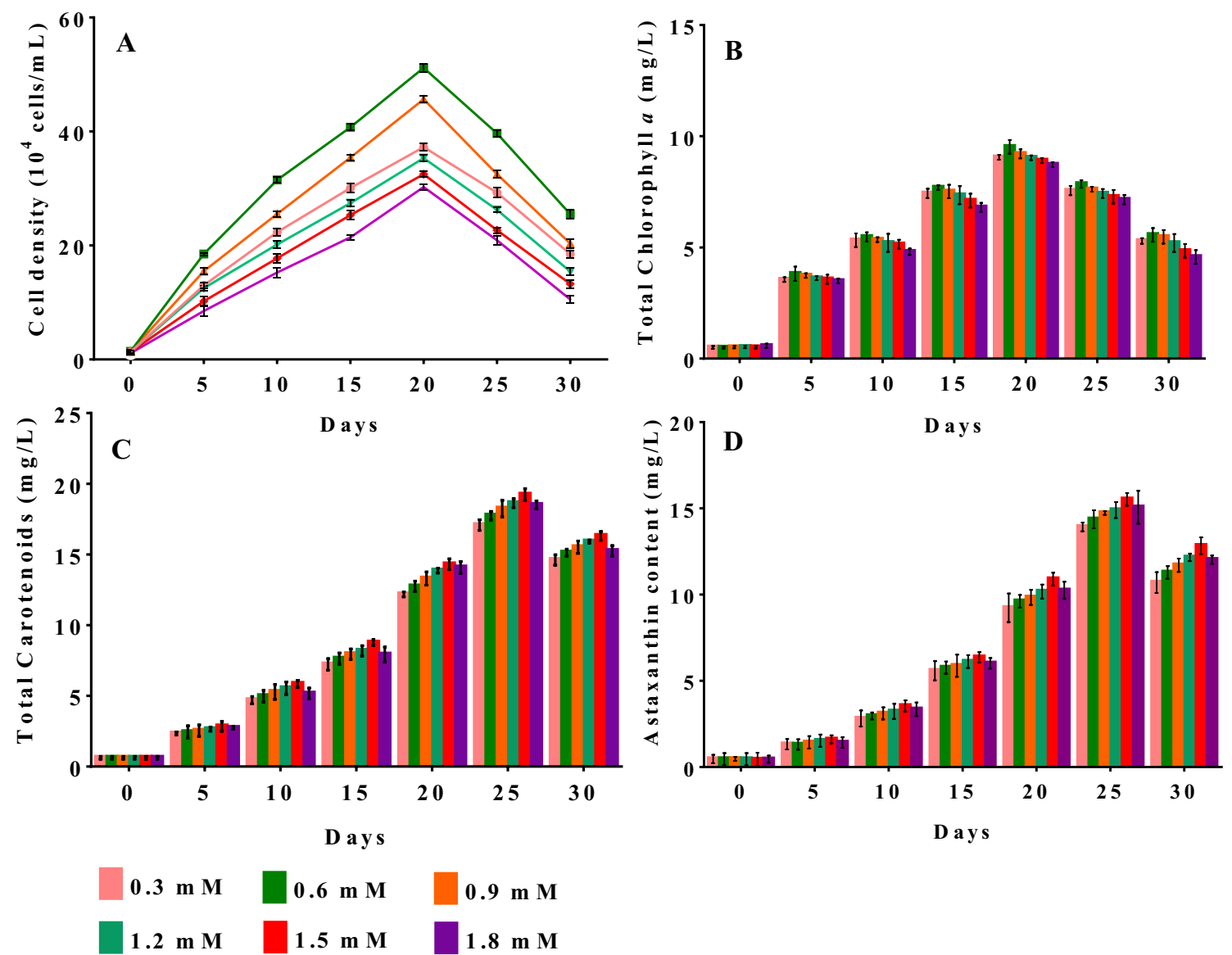

Fig. 6 Effect of different concentration of commercial $\mathrm{NaHCO}_{3}$ on a cell number (a), chlorophyll a (b), total carotenoids (c) and astaxanthin content (d) isolate of $\mathrm{H}$. lacustris HPI-001 at different intervals in laboratory conditions

contamination while grown at a $\mathrm{pH}$ of 7.5-7.8. In the present study, the commercial agriculture fertilizers such as NPK (17:17:17), $\mathrm{CH}_{4} \mathrm{~N}_{2} \mathrm{O},\left(\mathrm{NH}_{4}\right)_{2} \mathrm{HPO}_{4}, \mathrm{~K}_{2} \mathrm{CO}_{3}$ and $\mathrm{NaHCO}_{3}$ were used for the enhancement of growth and astaxanthin production in two strains of $H$. lacustris.

In common, nitrogen has a marked positive effect on growth and a negative effect on lipid accumulation due to the fact that microalgae can assimilate several nitrogen sources like nitrate, nitrite, ammonium and urea [47]. However, the nitrogen is a crucial element for microalgae's growth development, reproduction and other physiological activities [48]. Dominguez-Bocanegra et al. [49] reported that the $H$. lacustris culture in test BBM obtained a maximum cell density of $3.5 \times 10^{4}$ cells/ $\mathrm{mL}$, whereas Goksan et al. [47] obtained a maximum cell density of $2.6 \times 10^{4}$ cells $/ \mathrm{mL}$ with BG-11 medium plus different nitrogen sources. Similarly, Dalay et al. [21] reported that the commercial fertilizers (N:P:K 20:20:20) maximized cell concentration to $0.90 \mathrm{~g} / \mathrm{L}$ with growth rate of 0.150 day $^{-1}$. Since the microalga $H$. lacustris grow better in culture media with low N:P, high phosphorus levels favored the accumulation of biomass content [50].
However, when compared to nitrogen, phosphorus concentration over $50 \%$ caused a decrease in growth of culture [51]. In fact, differences in N:P concentrations may reduce algal growth for its adaptation to stress conditions [52].

NPK fertilizer is a low-cost nitrogen fertilizer and a relevant tool in microalgal culture, mainly for Chlorophyceae. In the current study, the Bold basal medium minus $\mathrm{NaNO}_{3}, \mathrm{~K}_{2} \mathrm{HPO}_{4} \cdot 3 \mathrm{H}_{2} \mathrm{O}$ and $\mathrm{KH}_{2} \mathrm{PO}_{4}$ was added with commercial agricultural fertilizer (N:P:K 17:17:17) and used to grow two different strains of $H$. lacustris. The isolate of $\mathrm{H}$. lacustris HPI-001 showed a maximum growth of $47 \times 10^{4}$ cells $/ \mathrm{mL}$ with specific growth rate of 0.117 day $^{-1}$. The growth attained here is higher than that reported by Dominguez-Bocanegra et al. [49] and Goksan et al. [47]. The pigment $\mathrm{Chl} a$ was increased to $7.13 \mathrm{mg} / \mathrm{L}$ at $1.2 \mathrm{mM}$ of commercial (N:P:K 17:17:17) in 15th and 20th day cultures. At $0.6 \mathrm{mM}(\mathrm{N}: \mathrm{P}: \mathrm{K} 17: 17: 17)$, the total carotenoids increased to $22.35 \mathrm{mg} / \mathrm{L}$ and astaxanthin content to $17.94 \mathrm{mg} / \mathrm{L}$ on 30th day. In strain H. lacustris SAG-19a exhibited a maximum cell number increased up to $42 \times 10^{4}$ cells $/ \mathrm{mL}$ specific growth of 0.122 day $^{-1}$. The 

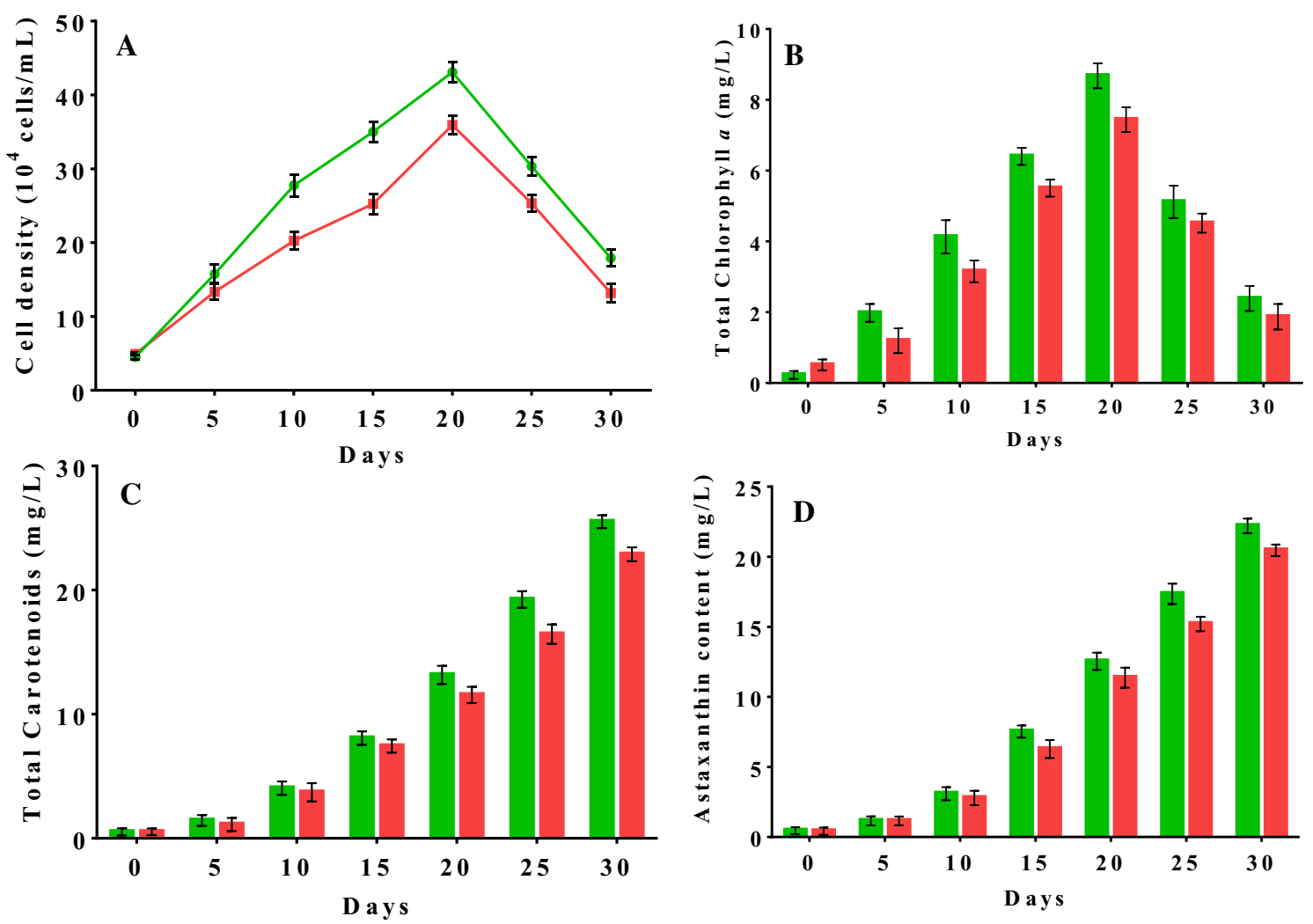

Modified HPI- $001 \mathrm{medium}$

M odified $3 \mathrm{~N}-\mathrm{B} B \mathrm{M}+\mathrm{V}$ m edium

Fig. 7 Comparative study of algae grown in modified $3 \mathrm{~N}-\mathrm{BBM}+\mathrm{V}$ medium and formulated commercial modified HPI-001 medium on a cell number (a), chlorophyll a (b), total carotenoids (c) and asta-

isolate $H$. lacustris HPI-001 increased in growth (11\%), pigment $\mathrm{Chl} a(14 \%), \mathrm{Chl} b(10 \%)$, total carotenoids (10) and astaxanthin content (16\%) was more than control of H. lacustris SAG-19a.

It has been reported that nitrate is an important nutrient supplement, affecting the growth and biomass accumulation in the microalgae. It is also able to significantly change the rates of cell metabolism through the transformation among different forms [53,54]. Moreover, nitrate was demonstrated to have a vital role for haematocyst germination in $\mathrm{H}$. lacustris [55]. Nitrogen depletion in the culture medium is a stress factor of $H$. lacustris, while high phosphorus concentration foregrounds algal growth in the vegetative stage which normally lasts between 9 and 20 days according to the ratio between biomass and cell activity [56]. Chlorophyll as a nitrogen-rich compound can be utilized as an intracellular nitrogen supporter to continue the growth of cells once nitrogen sources are decreased in culture. However, chlorophyll degradation may occur due to the reduced level of chlorophylls $a$ and $b$ with reutilizing of nitrogen for cells [57]. These xanthin content (d) isolate of $\mathrm{H}$. lacustris HPI-001 at different intervals in laboratory conditions

strategies are also employed in the H. lacustris cultures, and a remarkable enhancement of astaxanthin production is achieved due to nitrogen deficiency. For example, Fabregas et al. [55] reported the combined effects of light intensity and nutrient deficiency on astaxanthin synthesis by $H$. lacustris. In the present investigation, when grown in $\mathrm{BBM}$ devoid of $\mathrm{NaNO}_{3}$ and added with the commercial fertilizer $\mathrm{CH}_{4} \mathrm{~N}_{2} \mathrm{O}$, the $\mathrm{H}$. lacustris HPI-001 showed maximum growth of $41 \times 10^{4}$ cells $/ \mathrm{mL}$ with specific growth rate of 0.197 day $^{-1}$ and $H$. lacustris SAG-19a exhibited the maximum cell number of $32 \times 10^{4}$ cells $/ \mathrm{mL}$ with specific growth rate of $0.205 \mathrm{day}^{-1}$. The increase in growth (28\%) was higher than that of H. lacustris SAG-19a. H. lacustris $\mathrm{HPI}-001$ produced maximum concentration of $\mathrm{Chl} a$ $(8.26 \mathrm{mg} / \mathrm{L})$ and $\mathrm{Chl} \mathrm{b}(4.13 \mathrm{mg} / \mathrm{L})$ at $3.3 \mathrm{mM} \mathrm{CH}_{4} \mathrm{~N}_{2} \mathrm{O}$ on 15th day. The $4.9 \mathrm{mM}$ of $\mathrm{CH}_{4} \mathrm{~N}_{2} \mathrm{O}$ supported the highest accumulation of total carotenoids $(18.49 \mathrm{mg} / \mathrm{L})$ and astaxanthin $(15.19 \mathrm{mg} / \mathrm{L})$ on 25 th day. The increase in pigments such as Chl $a(14 \%)$, Chl b (13\%), total carotenoids (15\%) and astaxanthin content (18\%) was higher compared to that of H. lacustris SAG-19a. 
Table 3 Comparative study on growth and astaxanthin content of H. lacustris HPI-001 and H. lacustris SAG-19a using agriculture fertilizers

\begin{tabular}{|c|c|c|c|c|}
\hline Different parameters conditions & $\begin{array}{l}\text { H. lacustris HPI-001 cell } \\
\text { number }\left(10^{4} \text { cells } / \mathrm{mL}\right)\end{array}$ & $\begin{array}{l}\text { H. lacustris SAG-19a cell } \\
\text { number }\left(10^{4} \text { cells } / \mathrm{mL}\right)\end{array}$ & $\begin{array}{l}\text { H. lacustris HPI-001 } \\
\text { Astaxanthin (mg/L) }\end{array}$ & $\begin{array}{l}\text { H. lacustris SAG-19a } \\
\text { Astaxanthin (mg/L) }\end{array}$ \\
\hline \multicolumn{5}{|l|}{$\mathrm{N}: \mathrm{P}: \mathrm{K}(17: 17: 17)(\mathrm{mM})$} \\
\hline 0.3 & $33 \pm 0.344$ & $33 \pm 0.444$ & $17.49 \pm .0 .414$ & $14.66 \pm 0.410$ \\
\hline 0.6 & $40 \pm 0.420$ & $35 \pm 0.350$ & $17.94 \pm 0.509$ & $15.37 \pm 0.455$ \\
\hline 0.9 & $43 \pm 0.527$ & $37 \pm 0.325$ & $17.57 \pm 0.503$ & $15.02 \pm 0.326$ \\
\hline 1.2 & $47 \pm 0.524$ & $40 \pm 0.515$ & $17.15 \pm 0.303$ & $14.72 \pm 0.510$ \\
\hline 1.5 & $37 \pm 0.422$ & $42 \pm 0.520$ & $16.81 \pm 0.419$ & $14.50 \pm 0.420$ \\
\hline 1.8 & $30 \pm 0.324$ & $38 \pm 0.210$ & $16.36 . \pm 0.286$ & $14.16 \pm 0.222$ \\
\hline \multicolumn{5}{|l|}{$\mathrm{CH}_{4} \mathrm{~N}_{2} \mathrm{O}(\mathrm{mM})$} \\
\hline 1.6 & $37 \pm 0.525$ & $25 \pm 0.447$ & $13.20 \pm 0.407$ & $11.35 \pm 0.467$ \\
\hline 3.3 & $41 \pm 0.338$ & $32 \pm 0.557$ & $13.85 \pm 0.481$ & $13.83 \pm 0.448$ \\
\hline 4.3 & $35 \pm 0.520$ & $29 \pm 0.407$ & $14.11 \pm 0.532$ & $12.13 \pm 0.435$ \\
\hline 4.9 & $31 \pm 0.544$ & $27 \pm 0.348$ & $15.19 \pm 0.509$ & $12.47 \pm 0.539$ \\
\hline 6.6 & $28 \pm 0.244$ & $24 \pm 0.532$ & $14.74 \pm 0.409$ & $12.84 \pm 0.285$ \\
\hline 8.3 & $25 \pm 0.243$ & $22 \pm 0.546$ & $14.53 \pm 0.307$ & $12.81 \pm 0.372$ \\
\hline \multicolumn{5}{|l|}{$\left(\mathrm{NH}_{4}\right)_{2} \mathrm{HPO}_{4}+\mathrm{K}_{2} \mathrm{CO}_{3}(\mathrm{mg})$} \\
\hline $100+50$ & $25 \pm 0.419$ & $22 \pm 0.510$ & $12.21 \pm 0.528$ & $11.54 \pm 0.450$ \\
\hline $150+100$ & $31 \pm 0.533$ & $26 \pm 0.425$ & $12.69 \pm 0.307$ & $11.99 \pm 0.525$ \\
\hline $200+150$ & $33 \pm 0.300$ & $30 \pm 0.520$ & $12.28 \pm 0.206$ & $11.76 \pm 0.310$ \\
\hline $250+200$ & $35 \pm 0.267$ & $28 \pm 0.310$ & $11.96 \pm 0.406$ & $11.51 \pm 0.520$ \\
\hline $300+250$ & $28 \pm 0.164$ & $24 \pm 0.255$ & $11.67 \pm 0.553$ & $11.33 \pm 0.425$ \\
\hline \multicolumn{5}{|l|}{$\mathrm{NaHCO}_{3}(\mathrm{mM})$} \\
\hline 0.3 & $37 \pm 0.444$ & $31 \pm 0.515$ & $13.93 \pm 0.374$ & $9.85 \pm 0.455$ \\
\hline 0.6 & $51 \pm 0.342$ & $34 \pm 0.325$ & $14.37 \pm 0.521$ & $12.71 \pm 0.420$ \\
\hline 0.9 & $46 \pm 0.536$ & $36 \pm 0.310$ & $14.73 \pm 0.345$ & $10.10 \pm 0.510$ \\
\hline 1.2 & $35 \pm 0.233$ & $41 \pm 0.215$ & $14.91 \pm 0.463$ & $9.84 \pm 0.525$ \\
\hline 1.5 & $33 \pm 0.144$ & $45 \pm 0.420$ & $15.53 \pm 0.370$ & $9.73 \pm 0.420$ \\
\hline 1.8 & $30 \pm 0.443$ & $39 \pm 0.443$ & $15.07 \pm 0.455$ & $9.51 \pm 0.510$ \\
\hline Modified HPI-001 medium & $43 \pm 0.351$ & $40 \pm 0.425$ & $22.21 \pm 0.357$ & $20.10 \pm 0.429$ \\
\hline $3 \mathrm{~N}-\mathrm{BBM}+\mathrm{V}$ medium (Control) & $37 \pm 0.320$ & $35 \pm 0.442$ & $20.45 \pm 0.549$ & $18.25 \pm 0.425$ \\
\hline
\end{tabular}

Each value is the means of three experiments with triplicate each $(n=3)$. Statistically the means of three experiments not significantly different $(P<0.05)$

Phosphorus is an important nutrient for algal growth. It is responsible for the energy transfer of cells and the formation of cell membranes and nucleic acids. Besides being a structural element in nucleic acid and phospholipids, it plays crucial roles in various biological functions such as energy transformation, activation of metabolic intermediates, signal transduction cascades and regulation of enzymes $[58,59]$. When compared to nitrate, phosphate has received less attention in the optimization approach and has long been considered to promote the growth at moderate or low concentration approximately $0.5 \mathrm{mM}[60$, 61 , while at the same time it can promote the carotenogenesis at higher concentration up to $0.9 \mathrm{mM}$ [60]. Harker et al. [62] reported that the carotenoids accumulation has been shown to be reduced when phosphate supply was increased above $0.85 \mathrm{mM}$. There are some few reports on
H. lacustris growth in N/P ratio close or below 1, but in all cases it was identified that the low N/P conditions were favorable for growth [20, 21,62]. Brinda et al. [63] reported that the high biomass and astaxanthin accumulation were achieved in $\mathrm{H}$. lacustris under phosphorus deficiency conditions. In our study, the $\mathrm{K}_{2} \mathrm{HPO}_{4} \cdot 3 \mathrm{H}_{2} \mathrm{O}$ and $\mathrm{KH}_{2} \mathrm{PO}_{4}$ in basal medium was replaced with commercial agricultural fertilizer (NH4) ${ }_{2} \mathrm{HPO}_{4}+\mathrm{K}_{2} \mathrm{CO}_{3}$ and both the strains were grown in it. In the $\mathrm{H}$. lacustris HPI-001 exhibited maximum cell number of $35 \times 10^{4}$ cells $/ \mathrm{mL}$ with a specific growth rate of 0.178 day $^{-1}$, in which the growth (16\%) was more than that of $H$. lacustris SAG-19a. Similarly, the photosynthetic pigment also increased as compared to the control on 20th days. The maximum accumulation of total carotenoids $(15.99 \mathrm{mg} / \mathrm{L})$ and astaxanthin content of $(12.69 \mathrm{mg} / \mathrm{L})$ in isolate $\mathrm{H}$. lacustris HPI-001 was on 25th days. Ping et al. 
[64] reported that only $11 \mathrm{mg} / \mathrm{L}$ carotenoids were obtained in phosphate deficiency conditions. In the isolate, the increase in carotenoids (15\%) and astaxanthin content (10\%) was more than that of $H$. lacustris SAG-19a.

The carbon rate characterizes algal nutrition rates and constitutes $40-50 \%$ of algal biomass, although biomass is 47-50\% in H. lacustris [65]. Moreover, based on the recent study, carbon mass fraction in $\mathrm{H}$. lacustris can range from 46 to $55 \%$ [66]. The enrichment of $\mathrm{CO}_{2}$ is a requirement for achieving high microalgal culture productivity. At the same time, high $\mathrm{CO}_{2}$ levels are frequently stressful to microalgae, particularly for their photosynthetic apparatus $[67,68]$. The recent research reported that the cultivation of $\mathrm{H}$. lacustris under high $\mathrm{CO}_{2}$ demonstrated that increasing $\mathrm{CO}_{2}$ percentage in the gas mixture used for the culture sparging to $5 \%$ is favorable for astaxanthin accumulation $[69,70]$. Ding et al. [71] reported that under steady-state conditions, astaxanthin content in H. lacustris was $0.41 \%$. The previous studies on the cultivation of $H$. lacustris have showed that acetate appears to be an important carbon source, enhancing both growth and carotenogenesis [45, $72,73]$. However, the effect of acetate was concentration dependent, higher concentrations inhibiting growth but markedly increasing astaxanthin content per cell [74]. Bicarbonate is widely used as a primary carbon source in suspended culture of photosynthetic microorganisms [68]. The present investigation used basal medium added with commercial $\mathrm{NaHCO}_{3}$ to grow $\mathrm{H}$. lacustris HPI-001 which showed a maximum growth of $51 \times 10^{4}$ cells $/ \mathrm{mL}$ with specific growth rate of 0.184 day $^{-1}$ and maximum chlorophyll production at $0.6 \mathrm{mM}$ of $\mathrm{NaHCO}_{3}$ on 20th day, whereas the increase in total carotenoids (13\%) and astaxanthin content (13\%) was at $1.5 \mathrm{mM} \mathrm{NaHCO}_{3}$ on 25 th day.

In batch culture processes, the optimal Haematococcus media produced a cell number of $6.25 \times 10^{4}$ cells $/ \mathrm{mL}$ after 14 days of culture with no astaxanthin being accumulated [65]. A report by Domìnguez-Bocanegra et al. [49] states that the maximal growth of $\mathrm{H}$. lacustris obtained was $3.5 \times 10^{4}$ cells $/ \mathrm{mL}$ in the BBM medium under continuous illumination $\left(177 \mu \mathrm{mol}\right.$ photons $\left.\mathrm{m}^{-2} \mathrm{~s}^{-1}\right)$ with continuous aeration (1.5 vvm). Based on the above observations, a modified medium was formulated and designed, named as formulated commercial modified HPI-001 medium. The algal strains grown in the above medium were compared with the modified $3 \mathrm{~N}-\mathrm{BBM}+\mathrm{V}$. The isolate $\mathrm{H}$. lacustris HPI001 showed maximum growth of $43 \times 10^{4}$ cells $/ \mathrm{mL}$ with a specific growth rate of 0.162 day $^{-1}$. The maximum synthesis of pigments was $8.68 \mathrm{mg} / \mathrm{L} \mathrm{Chl} a, 5.12 \mathrm{mg} / \mathrm{L} \mathrm{Chl} b$ on 20th day, while the maximum accumulation of total carotenoids $(25.51 \mathrm{mg} / \mathrm{L})$ and astaxanthin content $(22.21 \mathrm{mg} / \mathrm{L})$ was on 30th day in cultures using formulated modified HPI-001 medium. The H. lacustris SAG-19a culture serving as $H$. lacustris SAG-19a exhibited maximum growth of
$40 \times 10^{4}$ cells $/ \mathrm{mL}$. The maximum concentration of pigments $\mathrm{Chl} a(7.22 \mathrm{mg} / \mathrm{L})$ and $\mathrm{Chl} b(4.36 \mathrm{mg} / \mathrm{L})$ was on 20th day, while the maximum accumulation of total carotenoids $(23.59 \mathrm{mg} / \mathrm{L})$ and astaxanthin content at $(20.10 \mathrm{mg} / \mathrm{L})$ was on 30th day, when cultured in the formulated modified HPI-001 medium. A comparatively high growth rate and pigment production was observed in the indigenously isolated H. lacustris HPI-001 than in the H. lacustris SAG-19a, when both were cultured using the formulated modified HPI-001 medium. This indicates that a promising alternative, cheaper and reproducible medium can be formulated using commercial agricultural fertilizers for achieving higher biomass and pigment astaxanthin production from $\mathrm{H}$. lacustris.

\section{Conclusion}

From the present study, it is evident that the indigenous isolate of $\mathrm{H}$. lacustris HPI-001 exhibited increased growth and astaxanthin production in the formulated modified HPI-001 medium when compared to the H. lacustris SAG19a. This indicates that a promising alternative, cheaper and reproducible medium can be formulated using commercial agricultural fertilizers for achieving higher biomass and pigment astaxanthin production from $\mathrm{H}$. lacustris. It is important that the modified HPI-001 medium which was formulated in this study for the first time is a very costeffective medium compared to the control modified Bold basal medium ( $3 \mathrm{~N}-\mathrm{BBM}+\mathrm{V})$. Currently, the algal-based biotechnology companies and industries are looking for cost-effective solution for mass cultivation of commercially important microalga like $\mathrm{H}$. lacustris for maximum biomass production. Hence, the present investigations recommend the formulated modified HPI-001 medium as a best source for maximum content of biomass and astaxanthin production. The outdoor studies are under progress with Bayir Extracts Pvt. Ltd., Bangalore, India.

Acknowledgements The author Dr. SNR would like to thank M/s. Bayir Extracts Pvt. Ltd., Bangalore-560085, for providing the financial support. I would also like to thank Prof. R. Rangasamy for his valuable suggestion in this research work. Mr. KR, AJ, Ms. SKG are thankful to The Director, Centre for Advanced Studies in Botany, University of Madras for providing laboratory facilities.

Funding The author Dr. SNR grateful to the Bayir Extracts Pvt. Ltd., Banglore - 560085, India, (Grand No. ARC/UICIC/CAS/Dr.S.N./2014/77) for sponsored financial support through University Industry Community Interaction Centre, (UICIC) University of Madras, Chennai.

\section{Compliance with ethical standards}

Conflict of interest The authors declare that they have no conflict of interest. 


\section{References}

1. Chew KW, Chia SR, Show PL, Ling TC, Arya SS, Chang JS (2018) Food waste compost as an organic nutrient source for the cultivation of Chlorella vulgaris. Bioresour Technol 267:356-362. https://doi.org/10.1016/j.biortech.2018.07.069

2. Praveenkumar R, Lee K, Lee J, Oh YK (2015) Breaking dormancy: an energy-efficient means of recovering astaxanthin from microalgae. Green Chem 17:1226-1234. https://doi. org/10.1039/C4GC01413H

3. Lee SY, Cho JM, Chang YK, Oh YK (2017) Cell disruption and lipid extraction for microalgal biorefineries: a review. Bioresour Technol 244:1317-1328. https://doi.org/10.1016/j.biort ech.2017.06.038

4. Oh YK, Hwang KR, Kim C, Kim JR, Lee JS (2018) Recent developments and key barriers to advanced biofuels: a short review. Bioresour Technol 257:320-333. https://doi.org/10.1016/j.biort ech.2018.02.089

5. Ranga Rao A, Siew Moi P, Ravi S, Aswathanarayana RG (2014) Astaxanthin: sources, extraction, stability, biological activities and its commercial applications-a review. Mar Drugs 12:128152. https://doi.org/10.3390/md12010128

6. Koller M, Muhr A, Braunegg G (2014) Microalgae as versatile cellular factories for valued products. Algal Res 6:52-63. https://doi. org/10.1016/j.algal.2014.09.002

7. Kittikaiwan P, Powthongsook S, Pavasant P, Shotipruk A (2007) Encapsulation of Haematococcus pluvialis using chitosan for astaxanthin stability enhancement. Carbohydr Polym 70:378385. https://doi.org/10.1016/j.carbpol.2007.04.021

8. Wu ZY, Chen GY, Chong S, Mak N, Chen F, Jiang Y (2010) Ultraviolet- $B$ radiation improves astaxanthin accumulation in green microalga Haematococcus pluvialis. Biotechnol Lett 32:19111914. https://doi.org/10.1007/s10529-010-0371-0

9. Wayama M, Ota S, Matsuura $H$, Nango N, Hirata A, Kawano S (2013) Three-dimensional ultrastructural study of oil and astaxanthin accumulation during encystment in the green alga Haematococcus pluvialis. PLoS ONE 8:e53618. https://doi. org/10.1371/journal.pone.0053618

10. Christian D, Zhang J, Sawdon AJ, Peng CA (2018) Enhanced astaxanthin accumulation in Haematococcus pluvialis using high carbon dioxide concentration and light illumination. Bioresour Technol 256:548-551. https://doi.org/10.1016/j.biort ech.2018.02.074

11. Shah MMR, Liang Y, Cheng JJ, Daroch M (2016) Astaxanthin-producing green microalga Haematococcus pluvialis: from single cell to high value commercial products. Front Plant Sci. https:// doi.org/10.3389/fpls.2016.00531

12. Hagen C, Siegmund S, Braune W (2002) Ultrastructural and chemical changes in the cell wall of Haematococcus pluvialis (Volvocales, Chlorophyta) during aplanospore formation. Eur J Phycol 37:217-226. https://doi.org/10.1017/S09670262020036 69

13. Collins AM, Jones HD, Han D, Hu Q, Beechem TE, Timlin JA (2011) Carotenoid distribution in living cells of Haematococcus pluvialis (Chlorophyceae). PLoS ONE 6:e24302. https://doi.org/10.1371/ journal.pone.0024302

14. Suseela MR, Toppo K (2006) Haematococcus pluvialis-a green alga, richest natural source of astaxanthin. Curr Sci 90:1602-1603

15. Liu Y, Song X, Cao X, Yu Z (2013) Responses of photosynthetic characters of Skeletonema costatum to different nutrient conditions. J Plankton Res 35:165-176. https://doi.org/10.1093/plank $\mathrm{t} / \mathrm{fbs} 080$

16. Chekanov K, Lobakova E, Selyakh I, Semenova L, Sidorov $R$, Solovchenko A (2014) Accumulation of astaxanthin by a new Haematococcus pluvialis strain BM1 from the White Sea coastal rocks (Russia). Mar Drugs 12:4504-4520. https://doi. org/10.3390/md12084504

17. Solovchenko A (2012) Physiological role of neutral lipid accumulation in eukaryotic microalgae under stresses. Russ J Plant Physiol 59:167-176. https://doi.org/10.1134/S10214437120201 61

18. Solovchenko A (2013) Physiology and adaptive significance of secondary carotenogenesis in green microalgae. Russ J Plant Physiol 60:1-13. https://doi.org/10.1134/S1021443713010081

19. Chekanov K, Vasilieva S, Solovchenko A, Lobakova E (2018) Reduction of photosynthetic apparatus plays a key role in survival of the microalga Haematococcus pluvialis (Chlorophyceae) at freezing temperatures. Photosynthetica 56:1268-1277. https ://doi.org/10.1007/s11099-018-0841-5

20. Hagen C, Grunewald K, Xylander M, Rothe E (2001) Effect of cultivation parameters on growth and pigment biosynthesis in flagellated cells of Haematococcus pluvialis. J Appl Phycol 13:79-87

21. Dalay MC, Imamoglu E, Demirel Z (2007) Agricultural fertilizers as economical alternative for cultivation of Haematococcus pluvialis. J Microbiol Biotechnol 17:393-397

22. Alkhamis $Y$, Qin JG (2015) Comparison of $N$ and $P$ requirements of Isochrysis galbana under phototrophic and mixotrophic conditions. J Appl Phycol 27:2231-2238. https://doi. org/10.1155/2013/983465

23. Rodrigues MS, Ferreira LS, Converti A, Sato S, Carvalho JC (2010) Fed-batch cultivation of Arthrospira (Spirulina) platensis: potassium nitrate and ammonium chloride as simultaneous nitrogen sources. Bioresour Technol 101:4491-4498. https://doi. org/10.1016/j.biortech.2010.01.054

24. Lagus A, Suomela J, Weithoff G, Heikkila K, Helminen H, Sipura J (2004) Species-specific differences in phytoplankton responses to $\mathrm{N}$ and $\mathrm{P}$ enrichments and the $\mathrm{N}: \mathrm{P}$ ratio in the Archipelago Sea, northern Baltic Sea. J Plankton Res 26:779-798. https://doi. org/10.1093/plankt/fbh070

25. De Morais MG, Costa JAV (2007) Biofixation of carbon dioxide by Spirulina sp. And Scenedesmus obliquus cultivated in a threestage serial tubular photobioreactor. J Biotechnol 129:439-445. https://doi.org/10.1016/j.jbiotec.2007.01.009

26. Zhu J, Rong J, Zong B (2013) Factors in mass cultivation of microalgae for biodiesel. Chin J Catal 34:80-100. https://doi. org/10.1016/S1872-2067(11)60497-X

27. Sivakumar SR, Arunkumar K (2009) Sodium, potassium and sulphate composition in some seaweeds occurring along the coast of Gulf of Mannar, India. Asian J Plant Sci 8:500-504. https://doi. org/10.3923/ajps.2009.500.504

28. Sipauba-Tavares LH, Donadon Lusser Segali AM, BerchielliMorais FA, Scardoeli-Truzzi B (2017) Development of lowcost culture media for Ankistrodesmus gracilis based on inorganic fertilizer and macrophyte. Acta Limnol Bras. https://doi. org/10.1590/S2179-975X3916

29. Tew KS, Conroy JD, Culver DA (2006) Effects of lowered inorganic phosphorus fertilization rates on pond production of percid fingerlings. Aquaculture 255:436-446. https://doi.org/10.1016/j. aquaculture.2006.01.003

30. Sipauba-Tavares LH, Pereira AML (2008) Large scale laboratory cultures of Ankistrodesmus gracilis (Reisch) Korsikov (Chlorophyta) and Diaphanosoma biergei Korinek, 1981 (Cladocera). Braz J Biol 68:875-883. https://doi.org/10.1590/S1519-69842 008000400025

31. Yang Y, Kim B, Lee JY (2013) Astaxanthin structure, metabolism and health benefits. J Hum Nutr Food Sci 1(1003):1-1003

32. Perez-Lopez P, Gonzalez-Garcia S, Jeffryes C, Agathos SN, McHugh E, Walsh D (2014) Life cycle assessment of the production of the red antioxidant carotenoid astaxanthin by 
microalgae: from lab to pilot scale. J Clean Prod 64:332-344. https://doi.org/10.1016/j.jclepro.2013.07.011

33. Naguib YM (2000) Antioxidant activities of astaxanthin and related carotenoids. J Agric Food Chem 48:1150-1154. https:// doi.org/10.1021/jf991106k

34. Borowitzka MA (2013) High-value products from microalgaetheir development and commercialization. J Appl Phycol 25:743-756. https://doi.org/10.1007/s10811-013-9983-9

35. Panis G, Rosales Carreon J (2016) Commercial astaxanthin production derived by green alga Haematococcus pluvialis. A microalgae process model and a techno-economic assessment all through production line. Algal Res 18:175-190. https://doi. org/10.1016/j.algal.2016.06.007

36. Ferrante RJ, Browne SE, Shinobu LA, Bowling AC, Baik MJ, MacGarvey U, Kowall NW, Brown RH Jr, Beal MF (1997) Evidence of increased oxidative damage in both sporadic and familial amyotrophic lateral sclerosis. J Neurochem 69:2064-2074. https://doi. org/10.1046/j.1471-4159.1997.69052064.x

37. Fassett RG, Combes JS (2011) Astaxanthin: a potential therapeutic agent in cardiovascular disease. Mar Drugs 9:447-465. https ://doi.org/10.3390/md9030447

38. Van Chuyen H, Eun JB (2017) Marine carotenoids: bioactivities and potential benefits to human health. Crit Rev Food Sci Nutr 57:2600-2610. https://doi.org/10.1080/10408398.2015.1063477

39. Masoudi A, Dargahi L, Abbaszadeh F, Pourgholami MH, Asgari A, Manoochehri M, Jorjani M (2017) Neuroprotective effects of astaxanthin in a rat model of spinal cord injury. Behav Brain Res. https://doi.org/10.1016/j.bbr.2017.04.026

40. Kanz T, and Bold HC (1969) Physilogical studies. 9. Morphological and taxonomic investigations of Nostoc and Anabaena in culture, Univ. of Texas Publ. No. 6924, Univ. of Texas, Austin, TX. http://www.ccap.ac.uk

41. Guillard RRL, Ryther JH (1962) Studies on marine planktonic diatoms I. Cyclotella nana Hustedt and Detonula confervacea (Cleve) Gran. Can J Microbiol 8:229-239. https://doi.org/10.1139/ m62-029

42. Lichtenthaler HK (1987) Chlorophylls and carotenoids: pigments of photosynthetic biomembranes. Methods Enzymol 148:350382. https://doi.org/10.1016/0076-6879(87)48036-1

43. Davies BH (1976) Carotenoids. In: Chemistry and biochemistry of plant pigments, pp 38-165

44. Aflalo C, Meshulam Y, Zarka A, Boussiba S (2007) On the relative efficiency of two- versus one-stage production of astaxanthin by the green alga Haematococcus pluvialis. Biotechnol Bioeng 98:300-305. https://doi.org/10.1002/bit.21391

45. Goksan T, Ak I, Gokpinar S (2010) An alternative approach to the traditional mixotrophic cultures of Haematococcus pluvialis flotow (Chlorophyceae). J Microbiol Biotechnol 20:1276-1282. https://doi.org/10.4014/jmb.0909.09005

46. Gutman J, Zarka A, Boussiba S (2011) Evidence for the involvement of surface carbohydrates in the recognition of Haematococcus pluvialis by the parasitic blastoclad Paraphysoderma sedebokerensis. Fungal Biol 115:803-811. https://doi.org/10.1016/j. funbio.2011.06.006

47. Goksan T, Ak I, Kilic C (2011) Growth characteristics of the alga Haematococcus pluvialis flotow as affected by nitrogen source, vitamin, light and aeration. Turk J Fish Aquat Sci 11:377-383. https://doi.org/10.4194/1303-2712-v11

48. Wang J, Han D, Sommerfeld MR, Lu C, Hu Q (2013) Effect of initial biomass density on growth and astaxanthin production of Haematococcus pluvialis in an outdoor photobioreactor. J Appl Phycol 25:253-260. https://doi.org/10.1007/s1081 1-012-9859-4

49. Dominguez-Bocanegra AR, Legarreta IG, Jeronimo FM, Campocosio AT (2004) Influence of environmental and nutritional factors in the production of astaxanthin from Haematococcus pluvialis.
Bioresour Technol 92:2089-2214. https://doi.org/10.1016/j.biort ech.2003.04.001

50. Tocquin P, Fratamico A, Franck F (2012) Screening for a lowcost Haematococcus pluvialis medium reveals an unexpected impact of a low N/P ratio on vegetative growth. J Appl Phycol 24:365-373. https://doi.org/10.1007/s10811-011-9771-3

51. Ashraf M, Javaid M, Rashid T, Ayub M, Zafar A, Ali S, Naeem M (2011) Replacement of expensive pure nutritive media with low cost commercial fertilizers for mass culture of freshwater algae, Chlorella vulgaris. Int J Agric Biol 13:484-490

52. Juneja A, Ceballos R, Murthy G (2013) Effects of environmental factors and nutrient availability on the biochemical composition of algae for biofuels production: a review. Energies 6:4607-4638. https://doi.org/10.3390/en6094607

53. Boussiba S, Vonshak A (1991) Astaxanthin accumulation in the green alga Haematococcus pluvialis. Plant Cell Physiol 32:1077-1082

54. Chen GQ, Chen F (2006) Growing phototrophic cells without light. Biotechnol Lett 28:607-616. https://doi.org/10.1007/s1052 9-006-0025-4

55. Fabregas J, Dominguez A, Maseda A, Otero A (2003) Interactions between irradiance and nutrient availability during astaxanthin accumulation and degradation in Haematococcus pluvialis. Appl Microbiol Biotechnol 61:545-551. https://doi.org/10.1007/s0025 3-002-1204-4

56. Sun H, Guan B, Kong Q, Geng Z, Wang N (2016) Repeated cultivation: non-cell disruption extraction of astaxanthin for Haematococcus pluvialis. Sci Rep. https://doi.org/10.1038/srep20578

57. Li Y, Sommerfeld M, Chen F, Hu Q (2008) Consumption of oxygen by astaxanthin biosynthesis: a protective mechanism against oxidative stress in Haematococcus pluvialis (Chlorophyceae). J Plant Physiol 165:1783-1797. https://doi.org/10.1016/j.jplph .2007.12.007

58. Hannon M, Gimpel J, Tran M, Rasala B, Mayfield S (2010) Biofuels from algae: challenges and potential. Biofuels 1:763-784. https ://doi.org/10.4155/bfs.10.44

59. Fan J, Cui Y, Wan M, Wang W, Li Y (2014) Lipid accumulation and biosynthesis genes response of the oleaginous Chlorella pyrenoidosa under three nutrition stressors. Biotechnol Biofuels 7:1. https://doi.org/10.1186/1754-6834-7-17

60. Borowitzka MA, Huisman JM, Osborn A (1991) Culture of the astaxanthin-producing green alga Haematococcus pluvialis. Effects of nutrients on growth and cell type. J Appl Phycol 3:295-304. https://doi.org/10.1007/BF00026091

61. Fabregas J, Dominguez A, Regueiro M, Maseda A, Otero A (2000) Optimization of culture medium for the continuous cultivation of the microalga Haematococcus pluvialis. Appl Microbiol Biotechnol 53:530-535. https://doi.org/10.1007/s002530051

62. Harker M, Tsavalos AJ, Young AJ (1996) Factors responsible for astaxanthin formation in the chlorophyte Haematococcus pluvialis. Bioresour Technol 55:207-214. https://doi.org/10.1016/09608524(95)00002-X

63. Brinda BR, Sarada R, Kamath BS, Ravishankar GA (2004) Accumulation of astaxanthin in flagellated cells of Haematococcus pluvialis cultural and regulatory aspects. Curr Sci Bangalore 87:1290-1294

64. Ping H, Duncan J, Barber J (2007) Astaxanthin accumulation in the green alga Haematococcus pluvialis. Effects of cultivation parameters. J Integr Plant Biol 49:447-451. https://doi.org/10.1 111/j.1744-7909.2007.00468.x

65. Del Campo JA, Garcia-Gonzalez M, Guerrero MG (2007) Outdoor cultivation of microalgae for carotenoid production: current state and perspectives. Appl Microbiol Biotechnol 74:11631174. https://doi.org/10.1007/s00253-007-0844-9

66. Chekanov K, Schastnaya E, Solovchenko A, Lobakova E (2017) Effects of $\mathrm{CO} 2$ enrichment on primary photochemistry, growth 
and astaxanthin accumulation in the chlorophyte Haematococcus pluvialis. J Photoch Photobiol B 171:58-66. https://doi. org/10.1016/j.jphotobiol.2017.04.028

67. Solovchenko A, Khozin-Goldberg I (2013) High- $\mathrm{CO}_{2}$ tolerance in microalgae: possible mechanisms and implications for biotechnology and bioremediation. Biotechnol Lett 35:1745-1752. https://doi.org/10.1007/s10529-013-1274-7

68. Ptushenko V, Solovchenko A (2016) Tolerance of the photosynthetic apparatus to acidification of the growth medium as a possible determinant of $\mathrm{CO}_{2}$-tolerance of the symbiotic microalga Desmodesmus sp. Biochem Mosc 81:1531-1537. https://doi. org/10.1134/S0006297916120142

69. Kang CD, Lee JS, Park TH, Sim SJ (2005) Comparison of heterotrophic and photoautotrophic induction on astaxanthin production by Haematococcus pluvialis. Appl Microbiol Biotechnol 68:237-241. https://doi.org/10.1007/s00253-005-1889-2

70. Cheng J, Li K, Yang Z, Zhou J, Cen K (2016) Enhancing the growth rate and astaxanthin yield of Haematococcus pluvialis by nuclear irradiation and high concentration of carbon dioxide stress. Bioresour Technol 204:49-54. https://doi.org/10.1016/j.biort ech.2015.12.076
71. Ding SY, Lee YK (1994) Growth of entrapped Haematococcus lacustris in alginate beads in a fluidized bed air-lift bioreactor. In: Phang SM, Lee YK, Borowitzka MA, Whitton BA (eds) Algal biotechnology in the Asia-Pacific Region. University of Malaysia, Kuala Lumpur, pp 130-133

72. Orosa M, Franqueira D, Cid A, Abalde J (2005) Analysis and enhancement of astaxanthin accumulation in Haematococcus pluvialis. Bioresour Technol 96:373-378. https://doi. org/10.1016/j.biortech.2004.04.006

73. Jeon YC, Cho CW, Yun YS (2006) Combined effects of light intensity and acetate concentration on the growth of unicellular microalga Haematococcus pluvialis. Enzyme Microb Technol 39:490-495. https://doi.org/10.1016/j.enzmictec.2005.12.021

74. Kakizono T, Kobayashi M, Nagai S (1992) Effect of carbon/nitrogen ratio on encystment accompanied with astaxanthin formation in a green alga, Haematococcus pluvialis. J Ferment Bioeng 74:403-405. https://doi.org/10.1016/0922-338X(92)90041-R

Publisher's Note Springer Nature remains neutral with regard to jurisdictional claims in published maps and institutional affiliations. 